\title{
MACROECONOMIC FORECAST FOR 2016-2018: THE ECONOMY IS PASSING THROUGH THE LOWEST POINT OF THE CURRENT CRISIS ${ }^{1}$ V. Averkiev, S. Drobyshevsky, M. Turuntseva, M. Khromov
}

Our macroeconomic forecast of the most probable scenarios for 2016-2018 indicates that the Russian economy will pass through the lowest point of the current crisis in mid-2016, and that thereafter, from H2 2016 onwards, it will start displaying signs of stabilization and even recovery. In 2017-2018, a modicum of GDP growth seems to be likely under practically each of the possible scenarios (unless a new dramatic decline in oil prices takes place). The expected GDP growth cannot be characterized as stable because it will not be caused by the restoration of the internal business cycle, the use of idle industrial capacities and an increase in the number of weekly hours actually worked per worker employed by an enterprise. Investment activity will remain weak. The recovery of retail turnover will lag behind the recovery of real personal income, while net personal savings will be on the rise. The rate of inflation will significantly decline, but the $4 \%$ inflation target is unlikely to be achieved by the end of the period 2017-2018.

In Q1 2016, the movement pattern displayed by a number of RF socioeconomic indicators showed an improvement on the same period of 2015. Thus, in Q1 2016, the rate of GDP decline reduced to 1.2\% (relative to Q1 2015; for reference: in Q1 2015, this index had amounted to 2.8\%). Investment dropped by $4.8 \%$, retail turnover - by $5.2 \%$, and real disposable personal income - by $4.7 \%$. Over the course of Q1 2016, the consumer price index increased by $2.1 \%$ (vs. by $7.5 \%$ during Q1 2015). In Q1, the average interest rate on new ruble-denominated loans stood at $13.3 \%$ per annum in nominal terms, or $5.7 \%$ in real terms (a rather high rate indeed). As of the end of Q1 2016, the monetary base had shown practically no changes and remained at the level of Rb 11 trillion. At the same time, ruble money supply (M2) slightly contracted, to $\mathrm{Rb} 35.4$ trillion.

The volume of foreign trade in US dollar terms continued to slide: in Q1 2016, exports and imports dropped by $33.2 \%$ and $15.2 \%$ respectively on Q1 2015.

In 2015, the average nominal ruble-to-USD exchange rate stood at $\mathrm{Rb} 74.6$. The real effective exchange rate of the ruble dropped by $8.3 \%$.

When assessing the development prospects for the Russian economy over the period 2016-2018, we considered two possible scenarios depending on the situation on the international oil market. We expect that under each of these scenarios, the year 2016 will see a further shrinkage of the Russian economy and a decline in the major macroeconomic indicators in real terms. In 2017-2018, the Russian economy will be able to begin a slow recovery, even if the external situation should follow the baseline pattern of development.

Under the basic scenario, it is expected that, in 2016-2018, the average annual price of Urals crude oil will amount to $\$ 40$ per barrel. At that

1 This paper was originally published in Online Monitoring of Russia's Economic Outlook No.10(28). 
price level, it would be unrealistic to hope that the Russian economy may indeed face a significant improvement of its foreign trade conditions. As far as foreign trade conditions are concerned, this scenario coincides with the baseline scenario of Russia's socio-economic development worked out by the RF Ministry of Economic Development in early May 2016 for a three-year period (until 2019) ${ }^{1}$.

Under the optimistic scenario, it is expected that, in 2016, the average annual price of Urals crude oil will increase to $\$ 45$ per barrel, and that the positive trend in the movement of oil prices on the international oil market will continue further ( $\$ 50$ per barrel in 2017 , and $\$ 60$ per barrel in 2018).

As has already been said, we expect that in 2016 real GDP will continue to decline under both scenarios: by $1.2 \%$ under the basic scenario and by $0.5 \%$ under the optimistic scenario. In 2017, its downward movement will come to an end, and then GDP will display growth by $0.3 \%$ under the basic scenario, and by $0.9 \%$ under the optimistic one. According to our forecast, in 2018 the economy will display growth by more than $1 \%$ : by $1.4 \%$ under the basic scenario, and by $1.9 \%$ under the optimistic scenario. The GDP deflator will decline following the slowdown in the inflationary processes in the Russian economy. Under the optimistic scenario, its value is expected to be slightly higher due to the rising prices of energy carriers and other mineral resources both in US dollar terms and in ruble terms.

Similar behavior patterns will also be displayed by the other economic activity indicators. Under the basic scenario, investment in fixed assets in 2016 will drop in real terms by $2 \%$, retail turnover by $4.8 \%$, and real disposable income by $2.3 \%$. For 2017 , it is forecasted that retail turnover will further decline by $0.4 \%$ alongside slight growth of investment (by $1.4 \%$ ) and real disposable income (by $0.5 \%$ ). In 2018 , growth will be demonstrated by all these indicators: investment will increase by $1.7 \%$, retail turnover by $0.8 \%$, and real disposable money income by $1.5 \%$.

The slower growth rate displayed by the household consumption index the existence of a lag between retail turnover in real terms and the growth rate of real disposable income - can be explained by the slow recovery of the retail lending market and the persistently prevalent saving-oriented behavior model displayed by the population. In our opinion, banks will demonstrate a higher activity with regard to issuance of housing loans, which will translate into a positive effect on the share of debt in household disposable income. Longer loan terms and low interest rates on housing loans will push down the debt servicing volume ${ }^{2}$.

Under the optimistic scenario, in 2016 all these economic indicators will likewise continue their downfall. The investment index will shrink by $1.6 \%$, retail turnover by $4.5 \%$, and real disposable income by $2.1 \%$. However, over the period 2017-2018, their movement patterns will shift into growth zone: investment in fixed assets will increase by $2.9 \%$ in 2017 (vs. by $2.4 \%$ in 2018), retail turnover in real terms by $0.1 \%$ (vs. $1.3 \%$ in 2018), and real disposable income by $1.3 \%$ (vs. by $2.8 \%$ in 2018). Inflation (measured as CPI) in 2016 will amount to $7.3 \%$, thereafter declining to $6.2-5.7 \%$ under the basic scenario and to $5.6-4.8 \%$ under the optimistic one.

1 http://economy.gov.ru/minec/about/structure/depMacro/20160506

2 This trend is noted in Khromov M. Banks: deterioration of assets quality and earnings reduction. Russian Economic Developments, 2015, No.11. 
If these conditions should become reality, the average nominal exchange rate of the ruble (in per annum terms) under the basic scenario will amount to $\mathrm{Rb} 67.6$ in 2016, to $\mathrm{Rb} 64.1$ in 2017, and to Rb 63.4 in 2018 respectively. Under the optimistic scenario it is expected that, in 2016-2019, the rubleto-USD nominal exchange rate will amount to $\mathrm{Rb} 66.3, \mathrm{Rb} 60.1$ and $\mathrm{Rb} 57.2$ respectively. The real effective exchange rate of the ruble in 2016 will increase by $2.7 \%$ under the basic scenario and by $6.9 \%$ under the optimistic one. Thereafter it will continue to be on the rise under both scenarios, thus in 2017 amounting to 3.9\% under the basic scenario (vs. to 3.3\% under the optimistic one), and in 2018 to $2.8 \%$ under the basic scenario (vs. to $6.2 \%$ under the optimistic one).

If the average annual price of oil in 2016 plunge below its 2015 level, the volume of foreign trade will continue to shrink. Under the basic scenario, exports will amount to $\$ 314.9 \mathrm{bn}$, and imports to $\$ 258.4 \mathrm{bn}$; thereafter, in 2017 and 2018, these two indicators will display some growth - to $\$ 322.2 \mathrm{bn}$ and $\$ 328.4 \mathrm{bn}$; and to $\$ 283.4$ and $\$ 300.7 \mathrm{bn}$ respectively. Under the optimistic scenario, exports and imports will demonstrate a somewhat similar movement pattern: decline to $\$ 330 \mathrm{bn}$ and $\$ 262 \mathrm{bn}$ in 2016, and modest growth in 2017 and 2018 to $\$ 358.2 \mathrm{bn}$ and $\$ 397.2$; and to $\$ 297 \mathrm{bn}$ and $\$ 319.8 \mathrm{bn}$ respectively.

Interest rates will stay at a rather high level. Under the basic scenario, the average nominal interest rate on ruble-denominated loans is expected to amount to $12.1 \%$ per annum (vs. real interest rate of $4.4 \%$ ) in 2016 ; to $11.4 \%$ (vs. real interest rate of 3.5\%) in 2017; and to 9.3\% (vs. real interest rate of 3.4\%) in 2018. Under the optimistic scenario for 2016, 2017 and 2018, the nominal interest rate will amount to $12.0 \%, 11.0 \%$ and $8.5 \%$ respectively (vs. the real interest rate of $4.4 \%, 3.7 \%$ and $3.5 \%$ respectively).

As seen from these projections, nominal interest rates on loans in 2018 will decline to the level that was typically observed over the period 2011-2012 (8.5-9.0\% per annum), when the lending market was recovering after the 2008-2009 crisis.

We predict that money supply indices will increase at a moderate rate. Under the basic scenario, growth of money supply (M2) in 2016 will amount to $8.8 \%$, and that of the monetary base - to $11.8 \%$; the corresponding indexes under the optimistic scenario will amount to $9.9 \%$ and $11.8 \%$ respectively. Their growth will continue in 2017 , so that under the basic scenario M2 will increase by $11.4 \%$ (vs. by $11.9 \%$ under the optimistic one), while the monetary base will increase by $7.3 \%$ and $8.9 \%$ respectively under the basic and optimistic scenarios. In 2018, M2 is expected to increase by $12.5 \%$ under the basic scenario and by $13.5 \%$ under the optimistic one. The monetary base under these two scenarios will increase by $6.8 \%$ and $7.5 \%$ respectively.

As in 2015, the main source of increasing money supply in 2016 will be the Reserve Fund ${ }^{1}$. And thereafter, over the course of the period 2017-2018, as it becomes depleted, we expect that the Bank of Russia will once again begin to refinance the banking sector, as budget deficit then will have to be covered by means of borrowing from domestic sources.

Thus, our estimates of the potential movement of Russia's main macroeconomic indicators under the most likely economic development scenarios

1 Sinelnikov-Murylev S.G., Trunin P.V. Sovereign wealth funds and monetary policy in Russia. Financial journal (In Russian), 2015, No.3(25), pp. 26-34. 
for 2016-2018 demonstrate that the lowest point of the current cycle will be passed somewhere in mid-2016, and that from H2 2016 onwards one may expect a revival of growth at a slow pace (or stabilization, if the external situation becomes unfavorable). Nevertheless, a stably positive growth rate of GDP can become achievable no earlier than in 2018.

We also expect that the 'situational' component of the growth rate will be slowly improving due to the recovery of the internal business cycle, the use of idle industrial capacities and an increase in the number of weekly hours actually worked per worker employed by an enterprise ${ }^{1}$. The existence of these factors can explain, among other things, the delayed recovery of investment in fixed assets and the persistently high real interest rates in the economy in face of moderate growth displayed by the lending market.

As far as the behavior of the inflation rate is concerned, we believe that it should be considered further in its own right. Under both scenarios, the Bank of Russia will not be able to achieve its stated aim of pushing the rate of inflation down to $4 \%$ per annum by the end of the period 2017-2018. However, the inflation rate has been steadily declining from year to year for a number of years, dwindling to its historic lows (below $6 \%$ in annual terms). In this connection we believe that the Russian Federation should not revise her inflation target, because an increase of that target can result in the strengthening of the inflationary expectations of economic agents, which will then further slow down the decline in the real inflation rate. Moreover, the obtained inflation projections for the end of the period 2017-2019 are, in fact, situated within the upper limit of the \pm 2 p.p. conventional range, and so, while not actually set as an element of Bank of Russia's policy, these values are quite common in the developing economies, where they are applied in the framework of inflation targeting policies, especially when those economies are suffering from negative external shocks produced by the situation on foreign markets ${ }^{2}$.

A transition to higher sustainable growth rates of GDP, a recovery in investment activity and bank lending, and a rapid reduction in the inflation rate will be possible if the economy undergoes more fundamental and purposeful changes than those that it has been experiencing so far (a rise in total factor productivity, the lifting of the current economic sanctions, a significant improvement of the foreign market situation, which implies not only a robust growth of prices for Russian exports but also an expansion of foreign markets necessary for increasing the physical volume of exports). However, such scenarios are highly unlikely in a short-term perspective (up to 2 years), and therefore we do not consider them in our forecast.

1 See also Drobyshevsky S.M., Kazakova M.V. GDP Growth Rate In 2015-2016: What its decomposition speaks of. Russian Economic Developments, 2015, Issue 12 (22), pp. 4-9.

2 For more details, see Bozhechkova A.V., Kiutsevskaya A.M., Trunin P.V. Inflation targeting: world experience. Money and Credit (In Russian), 2015, No.4, pp. 61-67. 


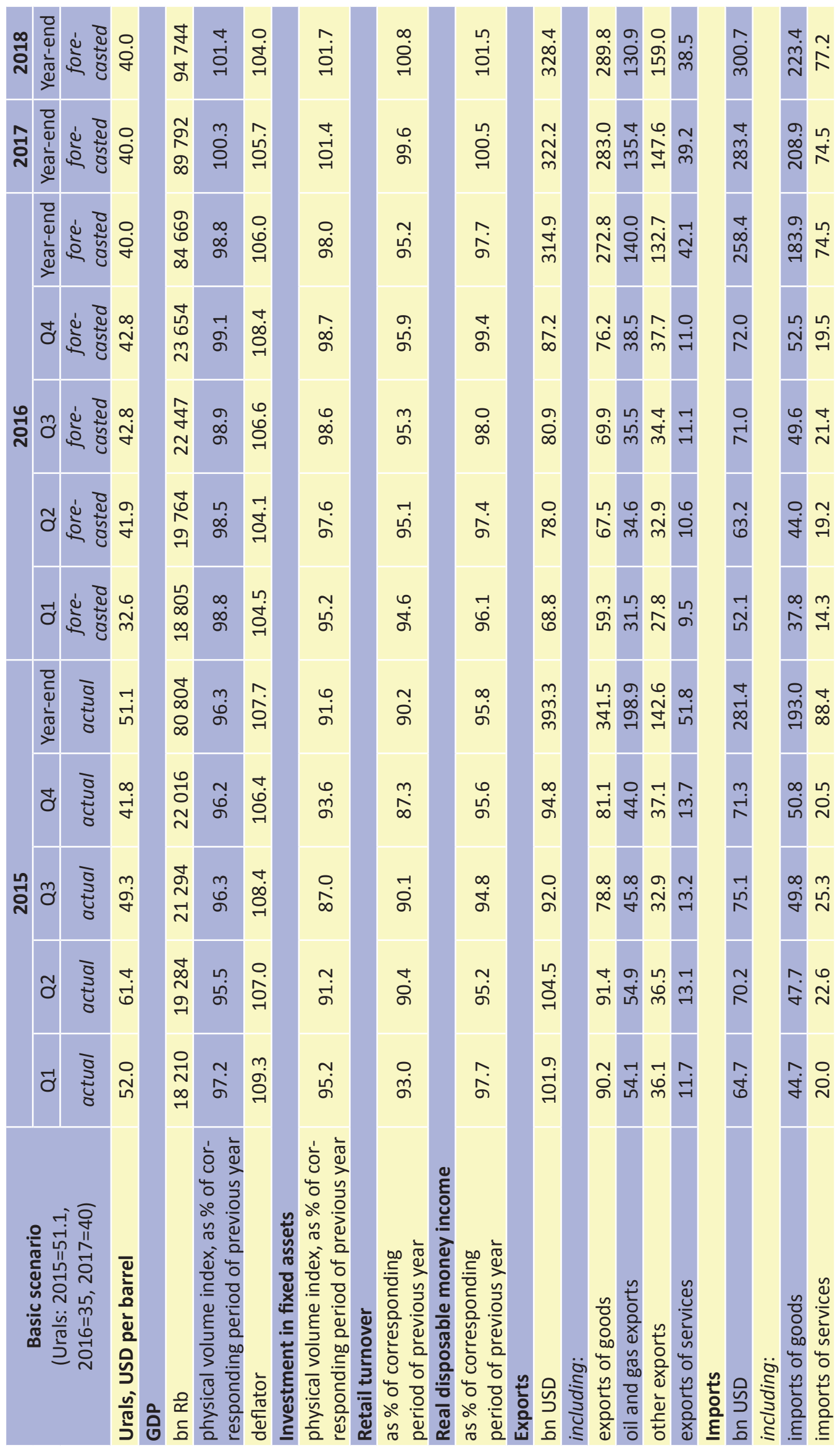




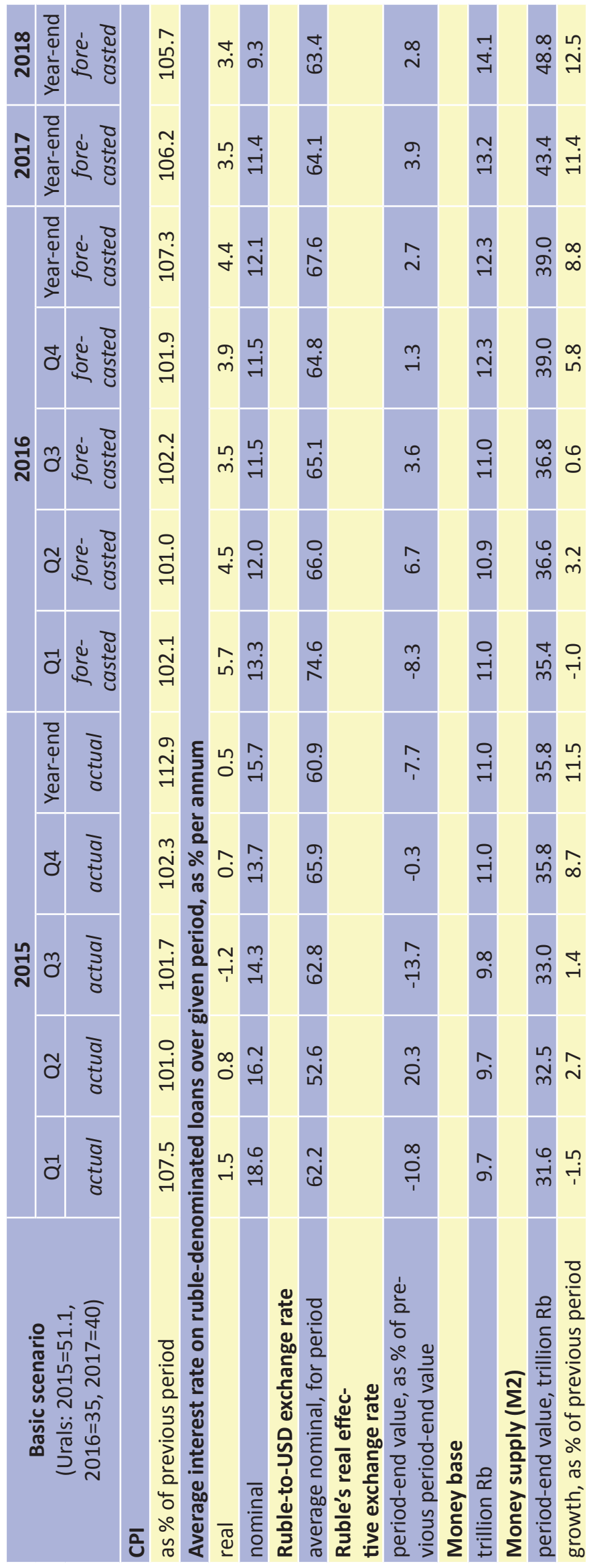




\begin{tabular}{|c|c|c|c|c|c|c|c|c|c|c|c|c|c|c|}
\hline $\begin{array}{l}\infty \\
\stackrel{2}{1}\end{array}$ & 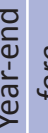 & : & & 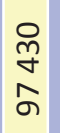 & مُ & 家 & 苛 & mi & 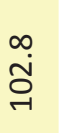 & ঙ্ & 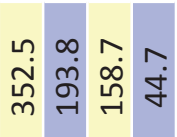 & $\begin{array}{l}\infty \\
\stackrel{\infty}{m} \\
\vec{m}\end{array}$ & 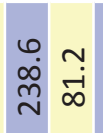 & $\stackrel{\infty}{\stackrel{\infty}{+}}$ \\
\hline ลิ & 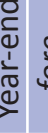 & 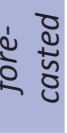 & & $\begin{array}{l}\text { ने } \\
\text { m } \\
\text { ने }\end{array}$ & $\begin{array}{l}0 \\
\stackrel{0}{0} \\
\stackrel{-}{-1}\end{array}$ & مُ & $\begin{array}{l}\text { g. } \\
\text { - } \\
\text { - }\end{array}$ & تُ & m & $\begin{array}{l}\text { N } \\
\text { ஸे } \\
\stackrel{n}{m}\end{array}$ & 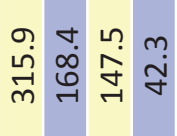 & م्. & $\begin{array}{l}-1 \\
\stackrel{0}{0} \\
\dot{N}\end{array}$ & ب. \\
\hline & 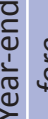 & & & $\begin{array}{l}\vec{I} \\
\stackrel{y}{f} \\
\stackrel{\infty}{\infty}\end{array}$ & ஸू & $\begin{array}{l}m \\
\stackrel{0}{0} \\
0\end{array}$ & $\stackrel{+}{\infty}$ & ผn & مุ & $\begin{array}{l}\circ \\
\stackrel{m}{m}\end{array}$ & 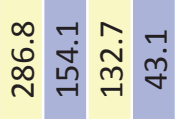 & 올 & 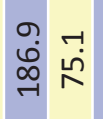 & $\stackrel{0}{i}$ \\
\hline & ठ & 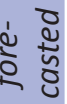 & & 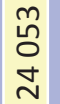 & 每 & ت্ & $\begin{array}{l}\ddot{g} \\
\dot{\sigma}\end{array}$ & ஜேं & ஜ் & $\begin{array}{l}\circ \\
\text { ดें }\end{array}$ & 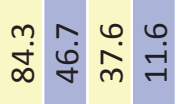 & $\begin{array}{l}m \\
\stackrel{N}{N}\end{array}$ & 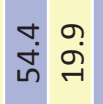 & o \\
\hline 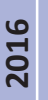 & o & 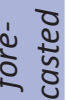 & & $\begin{array}{l}\text { సి } \\
\text { న } \\
\text { N }\end{array}$ & 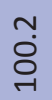 & 足 & $\begin{array}{l}\text { gं } \\
\text { g. }\end{array}$ & $\begin{array}{l}\infty \\
\text { ம் }\end{array}$ & $\vec{c}$ & $\underset{\infty}{\stackrel{\infty}{\infty}}$ & 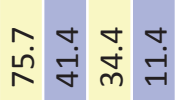 & $\stackrel{m}{i}$ & $\hat{\text { in }}$ & کై \\
\hline & $\widetilde{\sigma}$ & 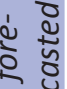 & & $\begin{array}{l}5 \\
0 \\
9 \\
-7\end{array}$ & $\stackrel{\llcorner}{\infty}$ & ت্ণ & $\begin{array}{l}\stackrel{\varphi}{a} \\
\text { ă }\end{array}$ & में & ウ̀ & $\stackrel{\circ}{\infty}$ & 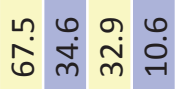 & $\stackrel{\sim}{\pi}$ & $\begin{array}{l}\circ \\
\dot{y} \\
\dot{7}\end{array}$ & i \\
\hline & $\vec{\sigma}$ & 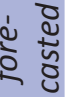 & $\begin{array}{l}\varphi \\
\text { m } \\
m\end{array}$ & $\begin{array}{l}\text { L } \\
\infty \\
\infty \\
\rightarrow\end{array}$ & $\begin{array}{l}\infty \\
\infty \\
\infty\end{array}$ & 管 & ผุं & $\begin{array}{l}\dot{\sigma} \\
\dot{\sigma}\end{array}$ & ஜேं & $\begin{array}{l}\infty \\
\infty \\
0\end{array}$ & 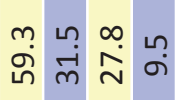 & กี่ & $\stackrel{\infty}{\stackrel{m}{m} \stackrel{m}{\sim}}$ & ָ̇ \\
\hline \multirow{5}{*}{ กิ } & 常 & \begin{tabular}{l}
$\bar{o}$ \\
\multirow{Z}{0}{} \\
0
\end{tabular} & تُ & 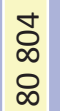 & $\begin{array}{l}m \\
\mathscr{\leftrightarrow}\end{array}$ & & $\begin{array}{l}\stackrel{0}{-} \\
\text { ने }\end{array}$ & ஜ̊ & $\begin{array}{l}\stackrel{\infty}{n} \\
\text { ம் }\end{array}$ & 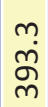 & 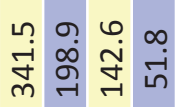 & $\stackrel{+}{i} \underset{\sim}{\stackrel{D}{~}}$ & 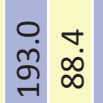 & 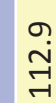 \\
\hline & d & 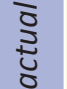 & 我 & $\begin{array}{l}\stackrel{0}{0} \\
\stackrel{1}{N}\end{array}$ & ஜֶं & 离 & $\begin{array}{l}\stackrel{\varphi}{n} \\
\text { g }\end{array}$ & $\stackrel{n}{\infty}$ & $\begin{array}{l}\text { ம் } \\
\text { ம் }\end{array}$ & $\begin{array}{l}\text { o̊ } \\
\text { बं }\end{array}$ & 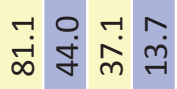 & $\stackrel{m}{i}$ & 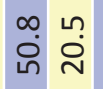 & ָָ \\
\hline & $\ddot{\sigma}$ & 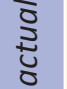 & $\begin{array}{l}m \\
g \\
g\end{array}$ & $\begin{array}{l}\text { సे } \\
\text { స }\end{array}$ & $\begin{array}{l}m \\
\mathscr{g}\end{array}$ & $\begin{array}{l}+ \\
\infty \\
\infty \\
-1\end{array}$ & $\underset{\infty}{\stackrel{0}{\infty}}$ & ஜ் & $\begin{array}{l}\infty \\
\dot{\sigma}\end{array}$ & $\begin{array}{l}\text { ㄱ. } \\
\text { n̆ }\end{array}$ & 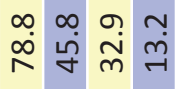 & 롯 & $\begin{array}{l}\infty \\
\stackrel{m}{\stackrel{n}{\sim}} \\
\stackrel{n}{\sim}\end{array}$ & i- \\
\hline & $\widetilde{\sigma}$ & $\begin{array}{l}\bar{s} \\
\text { t⿱艹 }\end{array}$ & ti & 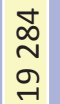 & $\begin{array}{l}\text { ñ } \\
\text { nू }\end{array}$ & 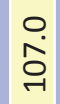 & 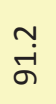 & ஜேं & ผู & $\stackrel{n}{\text { d }}$ & 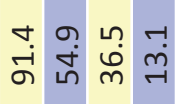 & חָ & 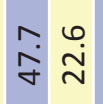 & 울 \\
\hline & $\widetilde{\sigma}$ & \begin{tabular}{l}
$\overline{3}$ \\
\multirow{U}{0}{} \\
0
\end{tabular} & $\begin{array}{l}0 \\
\text { ñ } \\
\text { ñ }\end{array}$ & $\begin{array}{l}\text { 건 } \\
\text { N } \\
\rightarrow\end{array}$ & $\frac{1}{a}$ & $\begin{array}{l}m \\
\text { ò } \\
0\end{array}$ & ڤึं & $\stackrel{\circ}{n}$ & ふa & مُ & 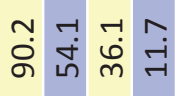 & f̊ & & \\
\hline
\end{tabular}

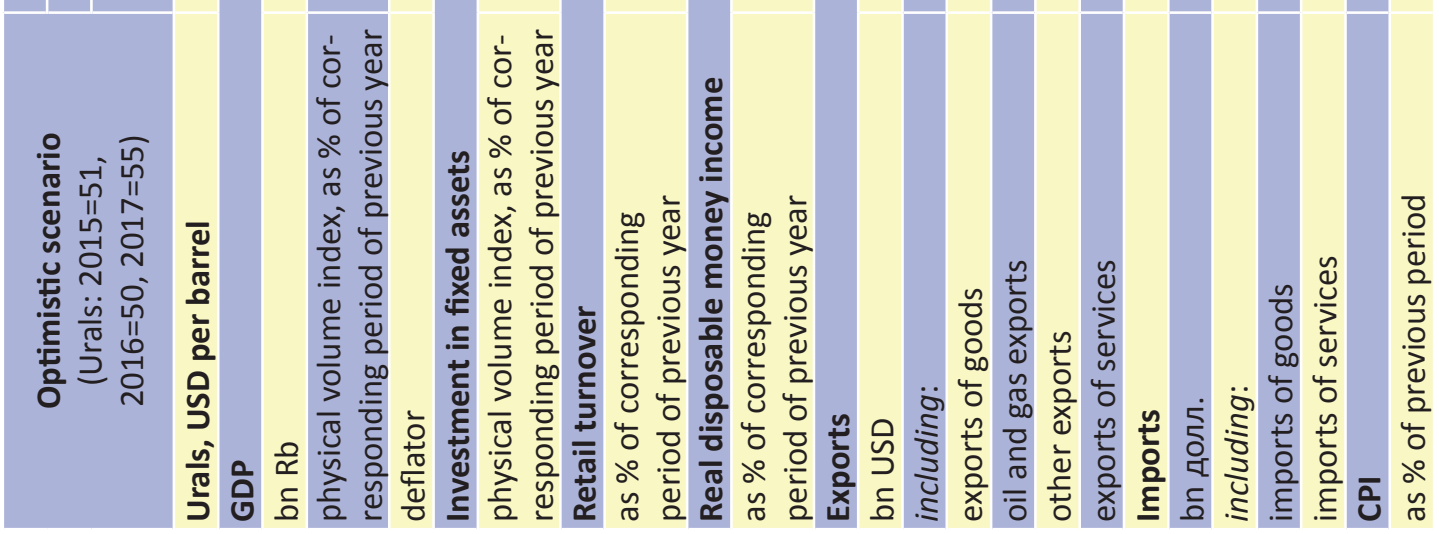




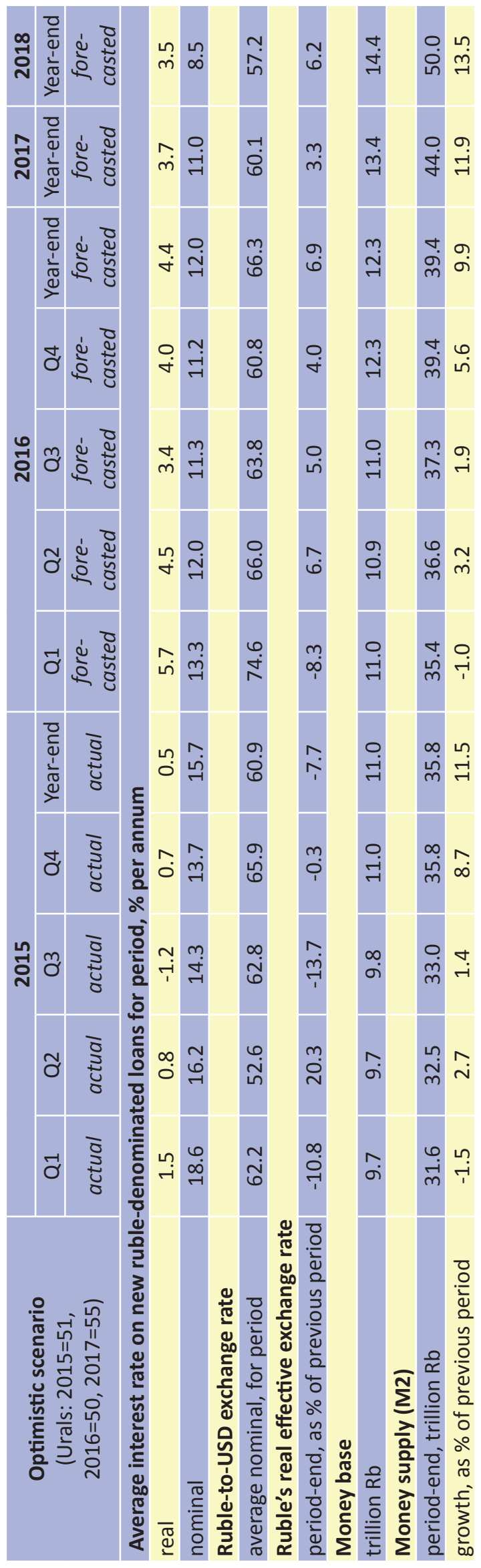

